\title{
Het hibernerend hart
}

Citation for published version (APA):

Borgers, M. (1993). Het hibernerend hart: Rust Roest. Janssen Research Foundation. https://doi.org/10.26481/spe.19931008mb

Document status and date:

Published: 08/10/1993

DOI:

10.26481/spe.19931008mb

Document Version:

Publisher's PDF, also known as Version of record

\section{Please check the document version of this publication:}

- A submitted manuscript is the version of the article upon submission and before peer-review. There can be important differences between the submitted version and the official published version of record.

People interested in the research are advised to contact the author for the final version of the publication, or visit the DOI to the publisher's website.

- The final author version and the galley proof are versions of the publication after peer review.

- The final published version features the final layout of the paper including the volume, issue and page numbers.

Link to publication

\footnotetext{
General rights rights.

- You may freely distribute the URL identifying the publication in the public portal. please follow below link for the End User Agreement:

www.umlib.nl/taverne-license

Take down policy

If you believe that this document breaches copyright please contact us at:

repository@maastrichtuniversity.nl

providing details and we will investigate your claim.
}

Copyright and moral rights for the publications made accessible in the public portal are retained by the authors and/or other copyright owners and it is a condition of accessing publications that users recognise and abide by the legal requirements associated with these

- Users may download and print one copy of any publication from the public portal for the purpose of private study or research.

- You may not further distribute the material or use it for any profit-making activity or commercial gain

If the publication is distributed under the terms of Article $25 \mathrm{fa}$ of the Dutch Copyright Act, indicated by the "Taverne" license above, 


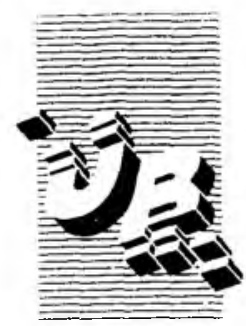

20 Dil. $8 \mathrm{geng}$

Rijksuniversiteil Limburg

Postbus 616

6200 MO Maastrıch!

Gelieve deze publicatie tijdig te retourneren of (telelonisch) verlenging van de uitleentermijn aan te vragen

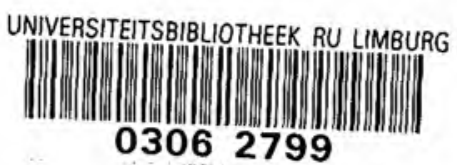




\section{Het hibernerend hart \\ Rust Roest}

$\operatorname{mit}_{V A C}$
007

Rede

uilgesproken bij de alanvaarding van het ambi van Bijzonder Hoogleraar Cardiovasculaire Celbiologie alan de Rijksuniversiteit Limburg op 8 oktober 1993

door

Dr. Marcel Borgers

Janssen Research Foundation 
Omslagontwerp : Inge Borgers

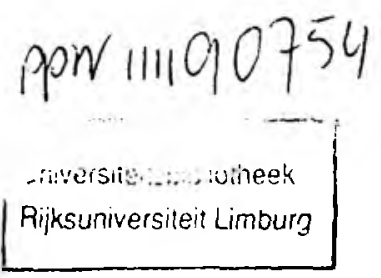


Mijnheer de Recror Magnificus.

Leden van het College van Bestum en ran hel Bestumr van de Faculleit der.

Genceskunde van de Rijksuniversiteit Limburg,

Leden van de Directie van Janssen Research Foundation.

Dames en heren collega's. fanilieleden en vienden.

Zeer gewardeerde oehoorders

Naası de vraag rond de betekenis van de titel van deze rede, kan ik me voorstellen dat er wel enkele randvragen bij u opkomen over de oprichting en invulling van de bijzondere leerstoel cardiovasculaire celbiologic. Eén van die vaggen zou kumnen zijn: "Hoe komt het dat iemand uit het bedrijfsleven. met het aureool van "toegepast onderzocker". alangezocht wordt om aan deze universiteit "lundamenteel onderzock" te verrichten? Ik kan u daarop geen pasklaar antwoord geven - ik kan u alleen maar zeggen dat die vraag niet wordt gesteld in het huis wall ik vandaan kom. Daar word namelijk geen onderscheid gemaakı tussen fundamenteel en toegepast onder\%oek. Volgens Dr. Paul Janssen bestain er maar twee soorten onderzock: goed en slecht. Uiteraard mag er volgens hem maar één soont toegelaten. c.q. gehonoreerd worden. In die zienswijze wordt hij trouwens bijgetreden door W. Von Braun, die datover hel volgende zei: "Basic research is what I do when I don't know what I am doing." Welke stempel men het ook moge geven, mijn onderzock hier in Maastricht mag dus maar tot die ene soort behoren.

$\mathrm{Bij}$ het leit dat deze leerstoel toegekend is aan een niet-Nederlander, zal men in het Europese Maasuricht wellicht veel minder lang stilstaan.

Belangrijker dan het "wie" of "waarom" is hel "wal": wat zal in het vakgebied Cardiovasculaire Celbiologic alan bod komen? Om dat te verduidelijken wil ik, vooraleer met het thema van deze rede aan te vangen, ter introductie enkele woorden wijden aan de algemene opdracht die alan deze bijzondere leerstoel verbonden is. U zult vlug merken dat de opdracht te maken heelt met morlologische aspecten van hart- en vaatziekten, want mijn verhaal zal doorspekt zijn van beelden. Ik heb het zelfs niet kunnen nalaten in het boekje dat deze rede samenvat enkele elektronenmicroscopische plaaljes op te nemen. Het moge u dan ook nict verbazen dat ik als morfoloog in hart en nieren de oude Chinese spreuk "Een beeld zegt meer dan 10.000 woorden" ten volle onderschrijl en als mijn lijfspreuk heb geadopteerd. Anders uitgedrukt, wat niet in beeld gebracht kan worden, versta ik niet zo best soms twijfel ik wel alan het bestaan ervan. 
19

In $18 \times 9$ schreel Goethe "Man erblickt nur was man schon weiß und verstehı." In die woorden ligt naar mijn mening de ware uitdaging voor de creatieve. innovatieve morfoloog vervat, mamelijk hel "nicuwe" in een beeld opsporen en het dwarsverband leggen mel de onderliggende fysiologie of pathofysiologic. Met andere woorden: de uitdaging voor de morloloog bestaat erin de woorden van Goethe te ontkrachten.

De enorme vooruitgang in het latste decennium op het gebied van de "ver-beeld-ing" vall relevante biologische substructuren en moleculen heeli de waarde van de moriologie sterk verhoogd en hatr als volwardige partner in het celbiologisch onderzoek doen accepteren. De tijd watarin morlologic werd bekeken als verluchtende of louter illustratieve discipline, is definitief voorbij. De valak gehoorde kritische bedenking l.o.v. morfologie uit het biochemisch-analytische kamp. met name dat hel gekozen plaatje altijd "moeders mooiste" is en niet noodzakelijk representatief is voor het beschreven fenomeen, is niet langer anvardbar, toch niet voor de morfoloog dic zich een volwardig wetenschapper wenst te noemen. Ik wil het niet nalaten hier even de al te beginselvaste biochemisch georiënteerde wetenschapper op de korrel te nemen. Wanneer die zijn denkwijze duidelijk wil maken. grijpt hij natr een potlood. construeert een schets van een cel (meestal een rechthoek) en begint dan ongebreideld ornamenten aan te brengen zoals bindingsplaatsen, kanalen. poortjes en vooral vele pijlijes. Tol hiertoe juich ik dat toe. ondat een schets uitstekend geschikt is om met behulp van weliswaar primitieve morfologie achter de watheid te komen. Maar al te vaak wordt die voorstelling als de enige echte warheid anzien, zonder dat er een sterke submicroscopische onderbouw anwezig is. De schets verzeilt in tekstboeken en wordt dogma voor ten minste 20 jaar. En dan ben ik als morfoloog minder gelukkig.

Hiermee zou ik deze zeer persoonlijke randbemerking willen afronden. Ik zou immers nog graag enkele collega's biochemici overhouden die samen met mij de geplande onderzoeksopdrachten in het kader van hart- en vaatziekten met succes willen voortzetten. 


\section{Ischemisch hartlijden}

Onder de hart- en vaatziekten nemen de kransslagaderaandoeningen (atherosclerose, trombose en spasmen) een belangrijke platats in: zij worden aanzien als de rechtstreekse oorzalak van ischemisch hartlijden. Naar schatting $50 \%$ van de kransslagaderpatiënten vertoont een ernstige angina pectoris of hartinsulficiëntie tengevolge van een myocardinfarct. Hoewel ischemisch hartlijden zich in de meeste westerse landen niet echt meer uitbreidt, blijft het veruit de belangrijkste doodsoorzaak. In de oosterse landen daarentegen - en vooral in landen zoals China - vertoont de incidentie van hart-en vaatziekten een duidelijk opwaartse tendens. als gevolg van de veranderende leefgewoonten.

Hoewel in de afgelopen decennia veel onderzoek verricht is nat de belangrijkste oorzaken van hart-en vaatziekten, zijn de inzichten in die aandoeningen beperkt. Dat geldt met name voor het ontstaan en de vroege ontwikkeling van atherosclerose. Het is duidelijk dat er een verband bestat tussen enerzijds hart- en valatziekten en anderzijds preëxistente alandoeningen, zoals hypertensie en diabetes en riskante leefgewoonten. De mechanismen die aan die relatie ten grondslag liggen, zijn echter minder duidelijk.

In het traditionele denkpatroon leidt de afsluiting van een kransslagader tot angina pectoris of een hartinfarct, mede afhankelijk van de crnst van de afsluiting en de mate van ontwikkeling van collaterale circulatie.

Ritmestoornissen zijn een gevreesde complicatie bij ischemisch hartlijden. Zowat $90 \%$ van de patiënten met een hartinfaret ontwikkelt potentieel zware ritmestoornissen, terwijl nalar schatting meer dan $40 \%$ van de dodelijke ongevallen het gevolg is van ventrikelfibrilleren. Hoewel onze kennis over de atard en het mechanisme van ritmestoornissen bij ischemisch hartlijden groeit, blijft het belangrijk onze inzichten te vergroten om de behandeling en preventie van die ritmestoornissen langs medicamenteuze weg te kunnen verbeteren.

De behandeling van ischemisch hartlijden beweegt zich voornamelijk op hel symptomatische vlak, zowel heelkundig als medicamenteus. Intensief onderzock naar de medicamenteuze behandelingsmogelijkheden verdient de voorkeur, omdat met goede geneesmiddelen in een relatief vroege fase van het lijden ingegrepen zou kunnen worden. Bovendien kan in een laat stadium van het lijden, wanneer om technisch-operatieve redenen de arteriële afsluiting of vernauwing niet meer op te heffen is, alleen nog verlichting gebracht worden met geneesmiddelen. 
In het lataste decennium is in dat traditioncle denkpatroon een duidelijke kentering waar te nemen. mede dank zij de beschikbataheid van nicuwe meemethoden voor he bepalen van de functie. structuur en her melabolisme van de hartspier enerzijds. en de ontwikkeling van nieuwe interventicmethoden anderzijds. Nochtans blijven de lacunes in onze kennis van de biochemische veranderingen die de hartspier ondergalat len gevolge van alsluiting of vermindering van de arteriële bloedoevoer veelvuldig en groot. Om een steeds betere behandeling van de onderliggende hatrtwilial te kunnen garanderen. zouden die gaten dan ook dringend opgevuld moeten worden.

Hel is ook die behoefic die ons bij he onderzocksprojece brengl dill momenteel loopt binnen hes Instituut voor Hart-en Valtziekten van Matastricht. in samenwerking met de Janssen Research Foundation uit Beerse. mijn thuishaven, de Katholieke Universiteit van Leuven en de Université Catholique de Louvain.

\section{Een nieuw concept: het hibernerend hart}

Een leck uilleggen wat een hibernerend hart precies inhoudt. is geen sinecure. Het hoeft dan ook geen verwondering te wekken dat het Shahbudin Rahimtoola, de geestelijke vader van het concept, verscheidene jaren heeft gekost om rijn collega's cardiologen duidelijk te maken wat hij er juist mee bedoelde. De cenvoudige lweeledigheid die he denken rond hartischemie bepalalde - ischemic van korte duur. leidend tot angina pectoris, en ischemic van lange duur, resulterend in myocardinfaret - is vandiag de dag duidelijk voorbijgestreede. In het latste decennium zijn nieuwe paradigmala van ischemische hartziekten beschreven. Dalartoe behoren het "stumned" myocard, "preconditioned" myocard en "hibernating" myocard (Heusch, 1992). Alhoewel zij het traditionele denken over myocardischemie verruimen, is de kennis van die verschijnselen vrij oppervlakkig. Het blijft overigens de vraag in hoeverre die concepten elkalar overlappen en of hun namen de lading wel dekken. Vooral met betrekking tot het hibemerend myocard is de twijfel groot.

Tot in 1975 was de algemeen geldende idee dat een alanhoudend slechte wandbeweging van de linkerventrikel bij rust een zeker gevolg was van een infarct. dus te wijten alan de aanwezigheid van "dood" weelsel. De kentering in dat "bewezen" feit kwam nadalt meerdere onderzoeksgroepen, mel als koploper Rahimtoola in de VS, een verklaring zochten voor de verbeterde 
wandbeweging van de slechte linkerventrikel na coronaire-bypasschirurgie. De verklaring voor die observatie kwam enkele jaren later en luidde als volgt: bij een aanzienlijk gedeclte van de ischemische hartpatiënten - vooral bij personen met een zekere graad van collaterale circulatic - wekt een chronische onderperlusie van het myocard cen defensieve respons op. waarbij de hartspier halar contractiekracht alanpast alan de anngeboden bloedtoevoer, c.q. encrgievoomiening. Eenvoudig uitgedrukt: "weinig bloed, weinig werk". De terminologie die aanvankelijk voor die aanpassing gebruikt werd, was "frozen state", "Iwilight", ofwel "hibernating" myocard. Er werd niel alleen aangenomen dat dal lenomeen bij veel patiënten voorkwam, maar tevens van zcer lange duur (jaren) kon zijn.

Toen in 1984 Rahimtoola het concept van hibernerend myocard boven de doopvont hicld, omschreef hij dat als volgt : "Hibernerend myocard is een loestand van een dysfunctioned linkerventrikel, als reactic op een sterk verminderde hartspierdoorbloeding. De dysfunctie komt neer op een verminderde tot alwezige contractic in het slecht doorbloede deel van de hartspier:" (Rahimtoola, 1985). Alhoewel de onderliggende structuur van die slecht werkende spier nauwelijks gedocumenteerd was, nam Rahimtoola aan dat die spier minimaal of niet beschadigd kon zijn. De reden daarvoor was dat na revascularisatic (door coronaire-bypasschirurgic) de contractickracht van de spier verbeterde. De hoofdkarakteristicken die an hibernerend myocard toegeschreven werden, zijn dus 1) slechte wandbeweging (verminderde contractickracht) 2) chronisch verminderde bloedvoorziening, 3) leefbaar myocardweefsel (afwezigheid van infaret) en 4) normalisering van de wandbeweging na hersiel van de bloedtoevoer.

In zijn in 1989 gepublicerde overzichtsartikel beschrijft Rahimtoola dat een hibernerend myocard frequent alangetoond werd bij verschillende klinische syndromen zoals instabiele angina, chronisch stabiele angina, na een myocardinfaret en bij bepaalde toestanden van hartfalen en cardiomyopathic.

\section{Consequenties en implicaties van het nieuwe concept}

Het is duidelijk dat het nieuwe concept nict alleen cen interessante theoric is, maar potentieel brede praktische consequenties heeft, vooral in de context van de progressic van hartlalen. De meest significante en mogelijk belangrijkste implicatie is dat het concept suggereert dat hartalen bij patiënten zonder myocardinfarct reversibel kan zijn. Anderzijds is het zeer goed denkbaar dat 
hibernerend (levend) weefsel voorkom nalast geünlarcteerd (dood) weefsel. wat het herstel van functic na coronaire-bypasschirurgie bij cen infarctpatiënt kan verklaren. Vooraleer het concept op zijn volle waarde te kunnen inschatten, zil op de volgende gebieden nog hard gewerkt moeten worden om te komen tot:

1) een betcre. betrouwbare en beter betalalbare methode om hibernerend myocard te diagnostiscren:

2) cen duidelijker beeld van de structuur en/of structurele remodelling van de hartspier in hibernerende loestand. De moleculair-biologische benadering van het hibernerend myocard is tot op de dag van vandaag nog volledig brakkliggend terrein:

3) de uitwerking van een betere strategie voor de behandeling van het hibernerend myocard.

\section{Diagnose van het hibernerend myocard}

De diagnoseproblematick draait in hoofdzaak rond de vraig of de dyslunelic in de beweging van het betrokken hartspiersegment (hypokinetisch, akinetisch of dyskinetisch) te wijten is aan de aanwezigheid van dood weefsel (als gevolg van een infaret) of aan niet-functionerende, maar leetbare cellen in dat segment. Er bestaan verschillende methoden om het problecm te benaderen, maar alle lijden aan dezelfde euvels, met name te onnauwkeurig en/of te duur. De combinatic van het meten van de wandbeweging met ventriculografie, regionale doorbloeding met de opname van radioacticf ammonium, en het lokale metabolisme met de opname van radioactief fluorodeoxyglucose (beide laatste metingen worden uitgevoerd met behulp van Postitron Emission Tomography (PET)), is één van de meest geavanceerde technieken om hibernerend myocard op te sporen (Tillisch et al. 1986). Het slecht samentrekkende deel van het myocard wordt als hibernerend bestempeld, wanneer er een ogenschijnlijke tegenstrijdigheid (mismatch) bestait lussen de doorbloeding en het metabolisme. Wanneer een slecht doorbloed gebied (lage ammoniumopname) een normal tot supranormaal metabolisme vertoont (hoge glucose-opname), wijst dat erop dat het onderliggende weefsel leefbaar, c.q. hibemerend is. Een slecht doorbloed gebied dat geen of weinig glucose opneemt, is naar alle waarschijnlijkheid dood weefsel als gevolg van een infarct. De échte diagnostische problemen inherent aan PET zijn de zeer beperkte beschikbaarheid van die apparatuur en de bijhorende hoge kosten. Nederland 
beschikt momentecl over zegge en schrijve één toestel, België over acht.

Nalast PET worden enkele andere methodes naar voor geschoven als waardevol alternatief. Tot deze behoren het meten van de regionale distributie van technetium-99 sestamibi in de hartspier en de opname van thallium bij inspanning. De predictieve waarde van de bovenvermelde diagnostische tests ligt tussen 75 en 85\% (Rahimtoola, 1989; Schelbert, 1991).

\section{Structuur van het hibernerend myocard}

De histologie van de onderliggende myocardstructuur bij hibernatie is nog niet uitvoerig beschreven. De beschikbare studies zijn fragmentarisch, louter kwalitatief en berusten hoofdzakelijk op lichtmicroscopie. De reden daarvoor is te zoeken in het feil dat het niet eenvoudig is om humaan hartweefsel van hibernerende segmenten in voldoende mate te vergaren voor histologisch onderzoek. Onlangs hebben wij, in samenwerking met onderzoeksgroepen van de Katholieke Universiteit van Leuven en de Université Catholique de Louvain, een inventariserend onderzoek afgerond over de histologie van het hibernerend myocard. Dat onderzoek, verricht op bioptmaterial afkomstig van 150 patiënten tijdens coronaire-bypasschirurgie, heeft aangetoond dat bij een aanzienlijk deel der patiënten het hibernerend myocard bestaat uit myocardcellen die zeer sterk veranderd zijn qua structuur, alhoewel ze niet van degeneratieve aard zijn. Die veranderingen worden geïllustreerd in de bijgevoegde figuur. Terwijl de normale hartspiercel gekenmerkt wordt door regelmatig gerangschikt contractiel materiaal (sarcomeren), dat de cel volledig opvult (figuur A), is in een cel uit het hibernerend myocard dat contractiele materiaal gedeeltelijk of geheel verdwenen en vervangen door glycogeen (figur B). Meerdere observaties tonen aan dat die cellen een fenotypische verandering hebben ondergaan, die wijst in de richting van dedifferentiatic, of een teruggaan naar een vroeger stadium van ontwikkeling. Die veranderingen zijn, naast de depletie van het contractiel materiaal en de stapeling van glycogeen, terug te brengen tot het voorkomen van grote kernen met een typisch willekeurige distributic van chromatine, een toename van ruw endoplasmatisch reliculum, de afbouw van georganiseerd sarcoplasmatisch reticulum, en een virtuele afwezigheid van T-tubulaire instulpingen van de celmembraan. Die celveranderingen gaan gepaard met cen toename van de extracellulaire ruimte, waardoor de myocardcellen minder geordend met elkaar in verbinding staan. In hoeverre die toename van bindweefsel, met als hoofdcomponent collageen, mede verantwoordelijk is voor de slechte 


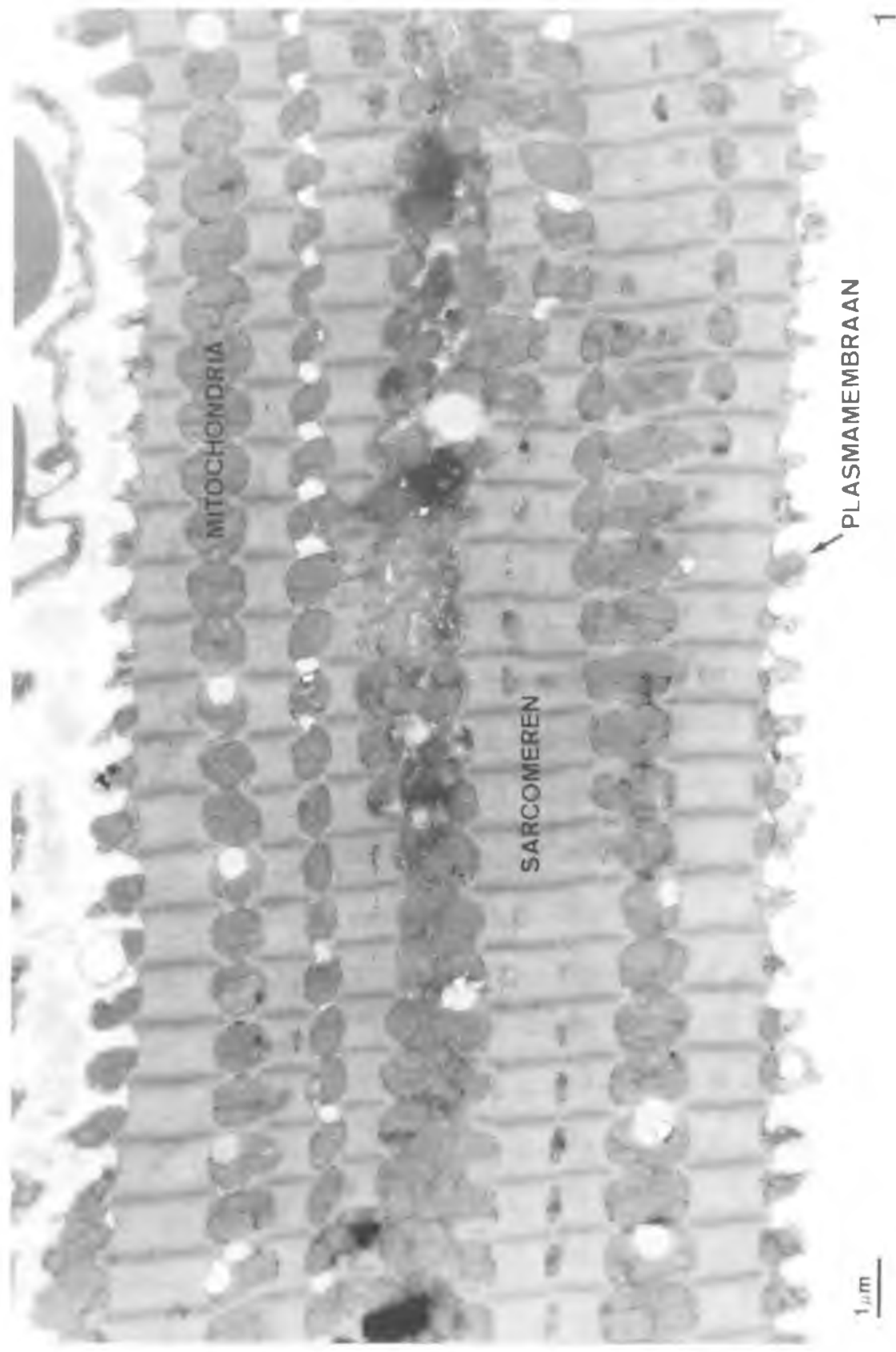




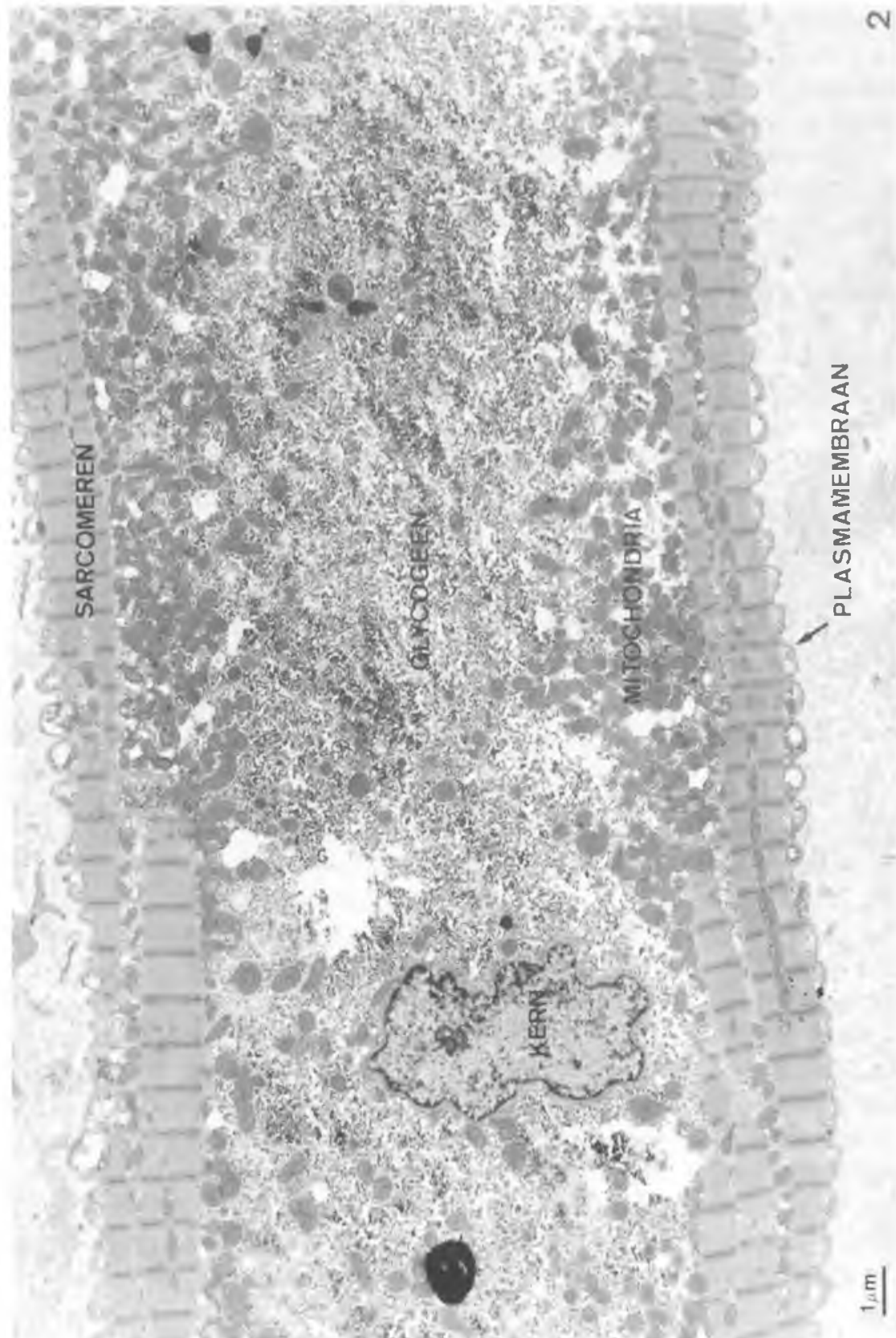


samentrekking van de hartspier. is nog niet uitgemaakt. Er blijkt trouwens een rechtstrecks (en mogelijk causaal) verband te bestan tussen het aantal hibernerende cellen en de hibernatiegraad enerzijds. en de toename van bindweefsel anderzijds. Na een kwantitatieve evaluatie blijkt er eveneens een directe correlatie te bestaan tussen de slechte samentrekking van de hartspier en de alanwezigheid van de bovenvermelde cellulaire en extracellulaire afwijkingen (Flameng el al.. 1984). Die structuurafwijkingen variëren (uiteraard) van patiënt tot patiënt en hebben betrekking op 10 tol $99 \%$ van de totale celpopulatic.

\section{De hibernerende cel: een fenomeen van dedifferentiatie?}

Dat is in elk geval het soon vraag waarvoor elke toegewijde celbioloog liguurlijk smelt!

Nu vaststaat dat er wel degelijk iets aan de hand is met de morfologische structuur van het hibernerend myocard - met duidelijke verschillen tegenover een normale hartspier, "stunned" myocard en infarctweefsel — rijst de vraag om welk type verandering het hier dan gaat.

De belangrijkste observatie die tot die vraag aanleiding geef, heeft te maken met de afwezigheid van normale hoeveelheden contractiel materiaal in anders gezond lijkende cellen. Aangezien andere ultrastructurele kenmerken evenzeer wijzen op de mogelijkheid dat de cellen van een hibernerend segment een vorm van dedifferentiatie hebben ondergaan, dient dat ook grondig gesubstantieerd te worden door een celbiologische karakterisatie met behulp van differentiatieparameters. Die benadering vormt dan ook de kern van het onderzoek dat in de Vakgroep Moleculaire Celbiologic \& Genetical hier in Maastricht verricht wordt. Om de hypothese van dedifferentiatie te ondersteunen, ligt het voor de hand de expressie van een reeks moleculaire differentiatiemerkers binnen die cellen te onderzoeken. Merkers voor de verschillende differentiatiestadia van de myocardcel omvatten de expressie en organisatiepatronen van contractiele en cytoskeleteiwitten, die met behulp van immunocytochemische technieken worden aangetoond. Wat de eiwitten van het contractiele apparaat betreft, gaat het o.a. om verschillende typen van myosine, actine, $\alpha$-actinine, nebuline, troponine, tropomyosine en titine. Spectrine, tubuline, ankyrine, vinkuline en desmine zijn typische componenten (eiwitten) van het cytoskelet en membraangebonden structuren. Die merkers zijn special gekozen, omdat de tot nu toe geobserveerde 
ultrastructurele veranderingen in hoofdzaak componenten van het contractiele apparaat, het cytoskelet en de celmembraan betreffen. De volgorde van expressie en organisatiepatronen zoals die gezien word tijdens de normale embryonale differentiatieprocessen kan met behulp van antilichamen tegen die eiwitten vrij nauwkeurig onderzocht worden. Zo kan een aantal typische stappen onderscheiden worden die bij de opbouw van een spiercel van beḷang zijn. Door het onderzoek naar de expressie, organisatic en lokalisatie van differentiatiemerkers kan uitgemaakı worden tot welke lase van het differentiatieproces hibernerende cellen behoren.

Immunohistochemische studies verricht in embryonale stadia van hartontwikkeling hebben ons inzicht in de expressievolgorde van specifieke en functioneel belangrijke componenten in die cel in de laatste jaren sterk doen toenemen. Met name de bouwstenen van het contractiele apparaat verschillende vormen van actine, myosine, tropomyosine, en titine - de eiwitten die voor de interactie van dat apparaat voor de membraan verantwoordelijk zijn, en cytoskeletaire eiwitten zoals desmine, vormen uitstekende merkers voor de verschillende stadia van functionele differentiatie (Borisov, 1991). Zo bleek uit studies, uitgevoerd in de Vakgroep Moleculaire Celbiologie \& Genelica, naar de ontwikkeling van de hartspier bij de muis, rat en het konijn dal litine één van de ecrste indicaloren voor de aanleg van het hart vormt. Dat eiwit is in de allervroegste stadia van ontwikkeling georganiseerd in aggregaten. Na de inductie van de desmineexpressie gaat hel over in een filamenteuze vorm en in latere stadia accumuleert het in een dwarsgestreepte organisatie. Samen met de expressie en organisatie van andere structurele eiwitten, zoals het recent in de Vakgroep Moleculaire Celbiologie ontdekte carnitine, kan zo een sequentie van de verschillende stadia van hartspierceldifferentiatie worden opgesteld.

\section{Rust Roest}

Zoals hierboven reeds werd uiteengezet, gaat bij een belangrijk deel der patiënten met chronisch hibernerend myocard een verbeterde bloedtoevoer na coronaire- bypasschirurgie of dotteren gepaard met een verbeterde werking. $\mathrm{Bij}$ sommigen gebeurt dat vlug na de klinische ingreep (na enkele uren tot enkele dagen) - in dat geval spreekt men van acute hibernatie. Anderen herstellen langzaam (na enkele weken) tot zeer langzaam (na enkele maanden 
tot een jaar): dan spreekt men van chronische hibernatie. Die sterke variatie hangt. zoals hoger beschreven. mogelijk samen met de structurele verandering in de hartspier vóor de klinische ingreep.

Een belangrijke vraiag die we tot hiertoe niet hebben gesteld. is de volgende: "Wat gebeurt er met het hibernerend myocard als de bloedtoevoer niet worde hersteld?"

Alhoewel ik ten volle besef dal dic vraag zeer moeilijk te beantwoorden is. wil ik me toch even op het speculatieve vlak bewegen en het gezegde "rust roest" hierbij betrekken. Die uitspralak slat zowel op de patiënt als op het fenomeen zell. De patiënt kan door goed geplande training zijn collaterale bloedvoorziening zodanig verbeteren dall de hibernatie daardoor wijkt of minstens stabiel blijh en de periode van hibernatie verlengd wordt. Rust is dus niet aan te raden. Wat het fenomeen zelf betreft. is het antwoord naar alle warschijnlijkheid dat - zonder enige interventic - het myocard degenereert en finaal infarceert. Die visie berust op de observatie dat de zuurstofvoorziening door de tijd heen niet spontalan verbetert. Er is integendeel een verdere aliname te verwachten, zodill er voor de hibernerende cellen te weinig zuurstof is om in rustoestand te overleven. Met als gevolg dat het "point of no return" bereikt wordt. De cellen sterven al" en de daardoor vrijgekomen ruimte wordt opgevuld door bindweelsel.

Niel alleen worden de degenererende hibernerende cellen opgeruimd, mala andere voorheen gezonde cellen komen in een hibernerende toestand terecht. Het rechtstreckse gevolg dairvan is dat er dagelijks kleine hoeveclheden cellen afsterven - in tegenstelling tot cen acuut infarct, wambij een massa cellen incens alsterft. Deze situatic kan het dus het best worden vergeleken met het chronisch ontstaan van een infarct. Zonder behandeling zal de steeds slechter functionerende hartspier daardoor in een fase van irreversibel falen komen, walrbij harttransplantatic als enige mogelijke uitweg overblijlt. Ondat de weg nalar het ultieme falen van de hartspier (m.a.w. het roestproces) lang is, blijft er gelukkig voldoende tijd over voor interventie. De enige weg om dat roestproces te stoppen, is het chronische zuurstoftekort te verhelpen. Dat kan gebeuren door het zuurstolatmbod te verhogen (langs fysieke of medicamenteuze weg), of door het zuurstofverbruik medicamenteus te reduceren.

Alhoewel tol op heden geen farmaca beschreven werden die de hibernerende toestand blijvend kunnen corrigeren, is het zeer wel mogelijk dal sommige de hibernatie gunstig kunnen beïnvloeden. Een optimale behandeling zou 
kunnen bestaan uit een combinatie van valatverwijding. zuurstofsparing en cytoprotectie. Tot die groep zouden theoretisch de nieuwste generatie cardioselectieve bela-blockers van het type nebivolol behoren.

\section{Uitdagingen voor verder onderzoek}

Naarmate bepaalde aspecten van hibernatic in het voorbije decennium beter onderkend werden - zoals de heterogenitcit in de lunctionele respons na revascularisatie en de variabiliteit in structurele adaptatic bij chronische hibernatie - kwamen nieuwe en belangrijke vragen naar boven die een uitdaging belekenen voor hed onderzock in het komende decennium. Een alantal van die vragen is van fundamentele alard:

- Is hibernatie een gerolg l'an anhoudende chronische ischemie of van korte periodes van ischemie. warbij de perioden van gereduceerde functie elkatr overlappen?"

Onderzoekers van de UCL (Vanoverschelde et al. . 1993) hebben aangetoond dat in collateraal ahankelijke segmenten met een chronisch verminderde wandbeweging niet noodrakelijk een continu verminderde bloedtoevoer gemeten word. Die gebieden vertoonden ultrastructurele celadapaties die gelijk zijn aan de klassieke hibernerende gebieden. De UCL-wetenschappers stellen diarom dat de verminderde wandbeweging en de onderliggende structuurveranderingen hel gevolg kunnen zijn van opeenvolgende korte periodes van ischemic, in tegenstelling tol chronische hypoperfusie, en dat die evenzeer de doorblocdings-, metabole. en morfologische correlaten zijn van een hibernerend myocard.

- War is de rol ban de roename van extracellalair materiaal in de dosfinctie van het myocard?

De mogelijkheid dient onderzocht te worden of de extracellulaire matrix al dan niet de determinerende factor is voor het uiteindelijke falen van de hartspicr.

- Is er een directe relatie anssen de verhoogde glacose-extractie (zoals vastgesteld met PET) en de glycogeenopstapeling in de hibernerende cellen?"

Die vraiag kan alleen malar uilgediept worden via een vergelijkend onderzoek op proefdieren, met een kwantitatieve bepaling van de glucose-extractic en 
glycogeenstapeling en de topografische distributic van radioakticf gemerkt glucose.

- Kan een gededifferentieerde cel redifferentiëren.'

Dat is meteen de hamvralag van deze studie. Enkel wanneer we over een relevant diermodel beschikken. kan aan een antwoord gewerkt worden.

- Welke rol heeft de moleculaire biologie in de karakrerisatie van het hibernerend myocard?"

De mogelijkheden van de moderne biologische technieken dienen aangegrepen te worden om tol een "fine-tuning" van het fenomeen hibernatic te komen. Wellicht kan men via transgene technicken de symthese reactiveren van de componenten die mogelijk onderdrukt zijn tijdens het proces van hibernatie, en zo de functionele organisatic van de slecht samentrekkende hartspier herstellen. Uiteraard moeten we cerst leren gaan, vooraleer te willen lopen. Met andere woorden: eerst kijken en inventariseren wat er misloopt en dan trachten in te grijpen.

\section{Samenvatting}

De naam hibernerend myocard wordt gegeven aan een slecht bewegend deel (hypokinetisch, akinetisch of dyskinetisch segment genoemd) van de hartspier zonder dat er aanwijzingen zijn voor een infarct. Tot hiertoe zijn de biochemische, structurele, en moleculaire celbiologische achtergronden van dat fenomeen nog onvoldoende bekend. Het wordt nog complexer als men ziet dat het herstel van de bloedtoevoer nu eens met een vlugge, dan weer met een langzame functieverbetering gepaard gaat. Recent onderzoek op biopten verkregen tijdens coronaire-bypasschirurgic toonde aan dat hel slecht functionerende deel van de hartspier bestaat uit cellen met een sterk veranderde structuur. Die veranderingen wijzen niet in de richting van degeneratie van hartspiercellen, maar doen eerder denken aan een teruggang naar vroegere stadia in de spierontwikkeling (dedifferentiatie). De klemtoon van ons toekomstige onderzoek over het fenomeen hibernatie zal dan ook liggen op de grondige typering van die slecht functionerende (slapende) cellen, met als doel kennis te verwerven over de factoren die het eventuele herstel van die cellen kumnen beïnvloeden. Het hibernerend myocard vormt een steeds belangrijker probleem in het geheel van hart- en vaatziekten. De huidige interventietechnieken laten weliswaar vaak een oorzakelijke 
behandeling toe, maar het probleem van de nog steeds falende hartspier blijft bij een aanzienlijke groep van patiënten onopgelost.

Concluderend kan ik stellen dat hibernatie, hoewel oorspronkelijk een verstandige overlevingsreactie van de hartspier, zonder interventie onverbiddelijk tot een falende hartspier leidt. Om te voorkomen dat rusten (hiberneren) overgat in roesten, dient onze kennis van het onderliggende celbiologisch gebeuren aanzienlijk aangescherpt te worden. Daarom zijn wij ervan overtuigd dat ons vakgebied cen fundamentele bijdrage kan leveren tot een betere definitie van het begrip hibernerend myocard en eventueel kan bijdragen tot de overgang van "ter plaatse rust" naar "voorwaarts, mars".

Naast het feit dat mijn verhaal een pleidooi is voor hartchirurgie en andere invasieve ingrepen zoals dotteren en thrombolyse, hoop ik dat het u enigszins duidelijk is geworden dat het fenomeen hibernerend myocard ook een interessant werkterrein vormt voor de morfologisch geörienteerde celbioloog. Zijn bijdrage mag gezien worden als een belangrijke schakel in het inzicht in de onderliggende pathofysiologie, dat zo onontberlijk is voor de ontwikkeling van een zinvolle medicamenteuze therapie. Een klein voorbeeld ter illustratie: indien een hibemerend myocard inderdaad gepaard gaat met een substantiële depletie van het contracticle materiaal van de hartspicrcel, dan zou een behandeling met hartspierondersteunende middelen van het type inotropica een slechte keuze zijn. Het werk van de morfoloog kan voorts bijdragen tot de verklaring waarom bij sommige patiëntenhet functieherstel na de chirurgische ingreep zo lang op zich laat wachten. Het is immers zeer goed denkbaar dat een structuur die zich soms na jarenlange ischemie zo drastisch gewijzigd heeft, niet in enkele dagen of weken kan normaliseren.

Ten slotte hoop ik dat de studenten van deze faculteit in het algemeen en de onderzockers die geïnteresseerd zijn in de problematiek van hart-en valatziekten in het bijzonder, uit deze globale benadering van het probleem hibernerend myocard - globaal, omdat ze gestructurecrd is op basis van allianties tussen klinische, celbiologische en biochemische disciplines cnige inspiratie kunnen putten voor hun toekomstig onderzoek aan deze faculteit. 


\section{Dankwoord}

Ik kom nu aan hel laatste deel van mijn rede. dal tevens het meest alangename is - voor velen onder u omdat he bijna gedaan is, voor mij ondal ik nu cindelijk de kans krijg om enkele personen te bedanken.

Leden ran hel College ran Bestumer en het Bestumr ran de Faculteil der Geneeskumde ran de Rijksumiersiten Limburg, het is met groot genoegen dat ik u bedank voor de oprichting van de bijzondere leerstoel Cardiovalsculaire Celbiologic aan de Faculteil der Geneeskunde en voor het in mij gestelde vertrouwen.

Leden ran de Raad ran Bestum van. Janssen Pharmacentica en de Janssen Research Fonndation, hier rertegemwoordigd door sijn oprichter Dr. Paul Jansse'n, zijn huidige President. Dr. Staf Van Reet. en leden ran de beleidsraad, mijn oprechte dank gaal naar u voor uw welwillende steun bij het initiëren van deze lecrstoel. I $\mathrm{k}$ mag de hoop koesteren dat dit initiatief in de nabije toekomst voor alle betrokken partijen zijn vruchten zal alwerpen.

Mijn wetenschappelijke loopbaan is gekenmerkt door een reeks gelukkige toevalligheden die hoofdzakelijk te maken hebben mel personen die me op het goede spoor hebben gezet of gehouden. Het begon met Jean Hugon, mijn cerste leermeester met wie ik elektronenmicroscopie en cytochemie bedreven heb. Die vakgebieden waren destijds hun kinderschoenen nog niet ontgroeid - er viel dus nog echt pionierswerk te verrichten. Na zes jaar samenwerking aan de universiteit van Sherbrooke, toevallig een universiteil die hetzelfde onderwijssysteem huldigt als Maastricht, nam ik afscheid van hem. Ik had immers besloten om te gaan werken bij Dr. Paul Janssen, toevallig een studiegenoot medicijnen van hem. Dr. Hugon deed mij toen uitgeleide met de woorden: "Allez-y, el n"oublie jamais qui l a habillé."

Mon cher Maîre, ik ben uw woorden niet vergeten en tol vandaag ben ik u als mijn wetenschappelijke "tailleur" dankbaar voor de kansen die u mij geboden hebt.

Ik kon toen nog niet vermoeden dat ik na mijn Sherbrooke-tijd bij een andere, ditmaal een grootmeester-"tailleur", zou terechtkomen.

Beste Di: Paul, ik wil u vandalag oprecht danken, niel alleen voor de vele jaren van sublieme wetenschappelijke leiding, mal vooral voor het veelvuldige "hart onder de riem steken".

De interesse voor hart-en valaieken is mij bijgebracht door twee wetenschappers dic beiden uit hetzelfde hout van "entrepreneurs" gesneden zijn. Het is daarom ook nict te verwonderen dat zij elk de leiding hebben van 
cen befaamd instituut voor hart- en vaatzickten.

Van Wolfgang Schaper heb ik matst de interesse ook het lef gekregen me bezig te houden met mocilijke problemen en daarover originele, soms gedurfde hypothesen los te laten.

Beste Wolfgang. uw ideeën en werkwijzen hebben mij steeds sterk gestimulecrd.

En dan kwam er Rob Reneman. Niemand die enigszins betrokken is bij deze lecrstoel zal craan Iwijfelen dat hij aan de basis ligt van de gebeurtenis die vandalag hier plaatsvindt. De Beerse-Maastricht "connection", speciaal die tussen de afdelingen Life Sciences van Janssen en Fysiologie van Maastricht, is een brug dic door Rob Rencman is geslagen en al 20 jaar door hem worde versterkt.

Beste Rob, ik ben u bijzonder veel dank verschuldigd, niet alleen voor het initiëren van deze leerstoel en de vele wijze raadgevingen die ik van u mocht ontvangen in de twee voorbije decennia, malar ook voor de jarenlange echte vriendschap. Ik hoop dat het Centrum voor Cardiovasculaire Celbiologic tor één van uw succesvolle initiatieven voor deze universiteit mag uitgroeien.

Beste collega Frams, het moet u opgevallen zijn dat ik elke keer met plezier naar Maastricht kom. Dat dank ik vooral alan de gulle gastvrijheid en de vriendschap dic ik van u en al uw medewerkers van de Vakgroep Moleculaire Celbiologic \& Genetica mag ontvangen, waarvoor ik u zeer erkentelijk ben. Dat de samenwerking tussen uw groep en de Beerse-laboratoria zich nict alleen beweegt op het vakgebied hart- en vaatzickten malar evenzecr groci en differentiatic insluit, maakt de band tussen onze groepen alleen maar steviger. lk hoop dat dic alliantic nog vele jaren mag duren en vele vruchten mag afwerpen.

Beste collega's uit Beerse, eigenlijk had ik dit slotbetoog met jullie moeten beginnen, want jullie verdienen een bijzondere creplaats in mijn dankwoord. Ik ben jullie zeer erkentelijk voor de vele jaren toegewijde samenwerking en hoop dal die in de tockomst met de hulp van de Maastricht-activitciten nog verstevigd kan worden.

Een laatste woord richt to mijn familie en wienden en speciad tot Ann, Inge en David, mijn trouwste supporters. Mijn dank voor jullic nimmer aflatende steun en zorg en vooral voor het vele geduld dat jullic dagelijks opbrengen om mij te blijven steunen en stimuleren.

Aan allen, nogmaals mijn oprechte dank voor uw aanwezigheid en uw belangstelling. 


\section{Literatuurlijst}

Borisov AB.:

Myolibrilogenesis and reversible disassembly of myolibrils as adaptive reactions of cardiac muscle cells

Acta Physiol Scand 599.71-80(1991)

Flameng W et al:

Multivariate analysis of angiographic histologic. and electrocardiographic data in patiënts with coronary heart discasc

Circulation 70. 7-17(1984)

Heusch G.:

Hibernation, stunning. ischemic preconditioning - neue Paradigmatia der koronaren Herakrankheit?

Z Kandiol 81. 596-609(1992)

Janssen PAJ.:

The prepared mind

Monogralic (1983)

Rahimtoola SH.:

A perspective on the dhree large multicenter randomized clinical trials of coronary bypass surgery for chronic stable angina

Circulation $\underline{2} ?$ (suppl. V). 12.3-1.35 (1985)

Rahimloola SH.:

The hibernating myocardium

Am Heart J 117.211-221 (1989)

Schelberl HR.:

Positron emission tomography for the assessment of myocardial viability. Circulation (suppl. I) 84 . 1-122-131 (1991)

Tillisch J ef al: :

Prediction of cardiac wall motion abnormalities predicted by using positron emission tomography

N Engl J Med 6. 884-888 (1986)

Vanoverschelde J-L et al.:

Mechanisms of chronic regional postischemic dysfunction in humans New insights from the study of noninfarcted collateral-dependent myocardium Circulation 87. 1513-1523 (1993) 